\title{
RELACIJE IMPLICITNIH TEORIJA INTELIGENCIJE I UVERENJA O ETIOLOGIJI INDIVIDUALNIH RAZLIKA RELEVANTNIH ZA OBRAZOVANJE: ULOGA BIHEJVIORALNE GENETIKE U NASTAVNIČKOJ PRAKSI
}

Cilj ovog istraživanja bio je ispitati relacije između implicitnih teorija inteligencije i uverenja koja nastavnici imaju o relativnom uticaju gena i sredine u objašnjenju individualnih razlika relevantnih za obrazovanje. S obzirom na to da su se inteligencija $\mathrm{i}$ osobine ličnosti najsistematičnije razmatrale $\mathrm{u}$ prethodnim istraživanjima $\mathrm{u}$ oblastima psihologije obrazovanja i bihejvioralne genetike, u ovom istraživanju združeno su se razmatrale kognitivne sposobnosti i osobine ličnosti. Cilj je bio ispitati i efekte koje ostvaruju znanje o bihejvioralnoj genetici i otvorenost prema bihejvioralno-genetičkim istraživanjima u obrazovanju u prethodno navedenoj relaciji. Dodatno, ispitana je i uloga sociodemografskih karakteristika nastavnika u objašnjenju razlika po svim ispitivanim karakteristikama. U istraživanju je učestvovalo 225 učitelja, nastavnika i profesora $(88.5 \%$ ženskog pola) sa teritorije Republike Srbije (prosečne starosti 42.9 godina). Rezultati ukazuju na značajne i direktne doprinose inkrementalnih teorija inteligencije u pozitivnom, te znanja iz oblasti bihejvioralne genetike u negativnom smeru na uverenja o značaju gena i sredine u kognitivnim sposobnostima i osobinama ličnosti. Teorije entiteta negativno doprinose otvorenosti nastavnika prema bihejvioralno-genetičkim istraživanjima. Razlike u odnosu na sociodemografske karakteristike nastavnika nisu detektovane. Nalazi ovog istraživanja ukazali su na značaj znanja iz oblasti bihejvioralne genetike i implicitnih teorija inteligencije u objašnjenju razlika u uverenjima prosvetnih radnika o značaju gena i sredine u oblikovanju individualnih razlika relevantnih za obrazovanje.

Ključne reči: bihejvioralna genetika, implicitne teorije inteligencije, N-N kontroverza, nastavnici.

\footnotetext{
*luna.radevic@uns.ac.rs
} 


\section{UVOD}

Kontroverza 'geni ili sredina' (eng. N-N: Nature-Nurture), jedna je od najstarijih u psihologiji (Ridley, 2003), a naučna oblast koja nudi empirijske nalaze kao potencijalni odgovor na ovu kontroverzu jeste bihejvioralna genetika. Bihejvioralna genetika je oblast koja se poslednjih godina sve više razvija, o čemu svedoči kako porast broja istraživanja u okviru ove oblasti, tako i sve veći uticaj na mnoge važne društvene aspekte, među kojima je i obrazovanje (Devonshire \& Domett, 2010). Trend sprovođenja bihejvioralno-genetičkih istraživanja karakterističan je i za Srbiju (npr. Smederevac et al., 2019), pri čemu je određen broj studija bio fokusiran upravo na varijable (npr. inteligencija) koje su značajne za proces obrazovanja (npr. Nikolašević i sar., 2014).

U kontekstu psihologije obrazovanja, primarni fokus bihejvioralnogenetičkih istraživanja usmeren je ka razrešenju debate da li su genski ili sredinski činioci važniji za oblikovanje različitih obrazovnih ishoda i ponašanja u vezi sa njima. Ipak, ova debata se proširila na znatno obuhvatniji dijapazon tema (Crosswaite, 2019). Dosadašnji nalazi ukazuju na to da genetski činioci imaju važnu ulogu u objašnjenju individualnih razlika u školskom uspehu (npr. Rimfeld et al., 2016), ali da su i sredinski uticaji, poput uticaja školske sredine (Gietz \& McIntosh, 2014), od velikog značaja za oblikovanje školskog postignuća. U prilog Prvom zakonu bihejvioralne genetike, prema kom su svi oblici ljudskog ponašanja pod uticajem gena $\mathrm{u}$ određenom stepenu (Turkheimer, 2000), govore decenije empirijskih istraživanja koja uključuju ispitivanje ponašanja relevantnih za proces obrazovanja (Crosswaite, 2019). Uprkos velikom broju studija koje su se bavile otkrivanjem relativnog doprinosa koji geni i sredina ostvaruju na razvoj i oblikovanje osobina, kognitivnih sposobnosti i drugih konstrukata relevantnih za obrazovanje (npr. Krapohl at al., 2014, Nikolašević i sar., 2014, 2020; Rimfeld et al., 2016, Plomin et al., 2016, Plomin \& von Stumm, 2018), veoma je mali broj onih koje su ispitivale stavove, uverenja i, na kraju, znanje koje prosvetni radnici imaju kada su u pitanju teme poput bihejvioralno-genetičkih nalaza i njihove primene $\mathrm{u}$ obrazovanju (npr. Crosswaite \& Asbury, 2018, Crosswaite, 2019, Walker \& Plomin, 2005).

\section{Uverenja nastavnika o značaju bihejvioralne genetike u obrazovanju}

Bez obzira na stav koji nastavnik može zauzeti prema istraživanjima u oblasti bihejvioralne genetike, teško je poreći veliki značaj koji bi ovi nalazi, uz korektnu interpretaciju i adekvatnu primenu u praksi, mogli imati za obrazovanje 
(Crosswaite, 2019). Nastavnici koji poseduju znanje iz ove oblasti, mogu da koriste nalaze istraživanja kao moćno sredstvo prilikom konceptualizacije i organizacije svojih časova (genetički senzitivne učionice) u cilju postizanja što veće nastavne efikasnosti (Haworth \& Plomin, 2012). Iz navedenih razloga neophodno je uključiti nastavnike ne samo kao ispitanike, već i kao učesnike u debatama na ovu temu, jer su upravo nastavnici ključni posrednici između obrazovne teorije i prakse (Crosswaite, 2019).

Prvo sistematsko istraživanje sprovedeno u cilju ispitivanja uverenja koja nastavnici imaju u vezi sa etiologijom individualnih razlika relevantnih za obrazovanje sprovedeno je pre više od jedne decenije (Walker \& Plomin, 2005). Nalazi ovog istraživanja pokazali su da nastavnici procenjuju genetske i sredinske faktore kao jednako značajne u oblikovanju osobina relevantnih za obrazovanje, sa izuzetkom problema u učenju, gde je veći značaj pripisan genima. Važan podatak koji su ovi autori istakli jeste da preko $80 \%$ nastavnika izjavljuje da u toku svog školovanja nije steklo znanje iz oblasti genetike. Na osnovu ovog podatka autori zaključuju da nastavnici svoja uverenja više zasnivaju na svakodnevnom iskustvu i nastavničkoj praksi, te na implicitnim stavovima i stereotipima, nego na znanju o (bihejvioralnoj) genetici (Walker \& Plomin, 2005). Nalazi Georgioa (Georgiou, 2008) ukazali su na to da su iskusniji nastavnici skloniji pripisivanju akademskog uspeha dispozicionim karakteristikama studenata (poput pola ili inteligencije), dok su studenti završnih godina i nastavnici sa manje pedagoškog iskustva češće uspeh pripisivali sredinski podstaknutim uticajima, poput napora i truda koji nastavnici ulažu u nastavu. Ovakvi rezultati dobijeni su i u istraživanju sprovedenom na američkim koledžima (Hildebrandt \& Eom, 2011). Zanimljiv je i nalaz kroskulturalne studije (Castera \& Clement, 2014) u kojoj je pokazano da znanje iz oblasti biologije i genetike, nema značajnog uticaja na uverenje nastavnika o relativnom doprinosu genskih i sredinskih činilaca u objašnjenju akademskog uspeha i osobina u vezi sa njim. Stoga se čini da bi naučna oblast koja kombinuje znanja iz genetike i bihejvioralnih nauka mogla nastavnicima da ponudi značajno jasnije zaključke i znanja u cilju njihove implementacije i unapređenja vaspitnoobrazovnog rada.

\section{Implicitne teorije inteligencije: definicija i značaj u kontekstu obrazovanja}

Sternberg (1985) definiše implicitne teorije inteligencije kao sistematska uverenja o prirodi inteligencije koja laici koriste radi samoevaluacije ili evaluacije drugih. Prema modelu Dvekove (Dweck, 1986), u pitanju je bipolarni konstrukt na čijem se jednom ekstremu nalazi teorija entiteta, a na suprotnom - teorija 
inkrementalnosti, dok istraživanja novijeg datuma ukazuju na dva zasebna faktora (npr. Abd-El-Fattah \& Yates, 2006, İlhan \& Cetin, 2013). Inkrementalna teorija podrazumeva uverenja o prirodi inteligencije kao o psihološkoj karakteristici koja je podložna promeni i usavršavanju tokom života, dok pristalice teorije entiteta inteligenciju vide kao datost i nepromenljivu konstantu.

Intelektualne sposobnosti su zasigurno jedna od najistraživanijih psiholoških karakteristika u oblasti bihejvioralne genetike (Plomin \& von Stumm, 2018). Uprkos tome nastavnici ne stiču znanje koje obuhvata nalaze ovih istraživanja, te svoje stavove u vezi sa intelektualnim sposobnostima i njihovom prirodom formiraju najčešće na osnovu svakodnevnog iskustva i implicitnih uverenja (Walker \& Plomin, 2005). Važnost ispitivanja implicitnih uverenja nastavnika ogleda se u pretpostavci da percepcija podložnosti inteligencije promenama može uticati na samu nastavničku praksu i njenu organizaciju (Georgiou, 2008). Rezultati dosadašnjih studija ukazali su na povezanost između implicitnih uverenja nastavnika i obrazovnih ciljeva koje postavljaju pred učenike, kao i na uticaj ovih uverenja na obrazovnu klimu koju će nastavnici kreirati u odeljenju (Leroy et al., 2007). Utvrđeno je i da nastavnici skloni inkrementalnim uverenjima pokazuju viši nivo samoefikasnosti (Leroy et al., 2007), dok nastavnici skloniji entiteskim stanovištima svoju ulogu vide kao pasivniju, a doprinos učenikovom usavršavanju ograničenim (Crosswaite \& Asbury, 2019). Pored toga, nastavnici skloni entitetskim uverenjima, teže menjaju unapred stvorene pretpostavke i predubeđenja o učenicima, čak i nakon većeg broja oprečnih informacija (Stipek, 2002). Nastavnici koji inteligenciju vide kao podložnu učenju i usavršavanju, češće vrednuju socijalne i praktične veštine kao pokazatelje inteligencije, što nije slučaj kod nastavnika koji inteligenciju definišu kao nepromenljivu karakteristiku (Lynott \& Woolfolk, 1994). Pored efekata na obrazovnu praksu, utvrđen je i značaj procene učitelja o inteligenciji učenika na njihove stavove o sopstvenoj inteligenciji, ali i o inteligenciji vršnjaka (Pretzlik et al., 2003).

Stavovi nastavnika o etiologiji individualnih razlika i implicitne teorije inteligencije

Uzevši u obzir relevantne nalaze dobijene u prethodnim istraživanjima koji ukazuju na to da nastavnici svoje procene zasnivaju mahom na ličnom iskustvu i ličnim teorijama, autorke Krosvajt i Azburi (Crosswaite \& Asbury, 2018) polaze od pretpostavke da se stavovi nastavnika o poreklu individualnih razlika u kognitivnim sposobnostima mogu povezati sa njihovim implicitnim uverenjima u vezi sa inteligencijom. Kao operacionalizaciju ove ideje, uzimaju model Dvekove (Dweck, 
1999) prema kom uverenja o fiksiranosti i uverenja orijentisana na rast (eng. fixed mindset, growth mindset) odražavaju kontrast predubeđenja o prirodi inteligencije kao urođenoj i nepromenjivoj datosti naspram shvatanja inteligencije kao karakteristike podložne promenama usled usavršavanja i učenja. Rezultati ovog istraživanja ukazali su na to da se razlike $u$ otvorenosti nastavnika prema genetičkim istraživanjima, kao i u znanju iz ove oblasti, mogu delom pripisati uzrasnim grupama učenika kojima predaju. Nastavnici koji predaju mlađim učenicima manje su upoznati sa nalazima bihejvioralne genetike, ali su i otvoreniji za njihovu primenu u praksi. Dodatni nalaz implicirao je zaključak da implicitna uverenja nastavnika ostvaruju značajan efekat $u$ objašnjenju njihove procene genskih i sredinskih činilaca intelektualnih sposobnosti učenika (Crosswaite \& Asbury, 2018). Nastavnici skloni uverenjima o fiksiranosti/nepromenjivosti inteligencije procenjuju genetske faktore kao značajnije u oblikovanju intelektualnih sposobnosti učenika.

\section{Problem istraživanja}

Uzevši u obzir rezultate navedenih istraživanja, može se zaključiti da implicitne teorije nastavnika $\mathrm{u}$ vezi sa prirodom inteligencije značajno utiču na njihovu praksu, zbog čega je posebno važno uključiti upravo prosvetne radnike u istraživanja ove teme. Glavni cilj ovog istraživanja je ispitati relacije između implicitnih teorija inteligencije i uverenja nastavnika o relativnom doprinosu gena i sredine u objašnjenju osobina relevantnih za obrazovanje, uzimajući u obzir efekte koje znanje iz ove oblasti i otvorenost nastavnika prema bihejvioralno-genetičkim istraživanjima u obrazovanju mogu ostvariti u ovoj relaciji. Važnost ispitivanja ove teme u našoj kulturi počiva na težnji da se ustanove potencijali nastavnika za usvajanje novih znanja iz bihejvioralne genetike, s obzirom na to da se veliki broj blizanačkih istraživanja $\mathrm{u}$ inostranstvu sprovodi u cilju unapređenja nastavnog procesa. U našoj zemlji prva blizanačka studija već je u povoju, te se ovim istraživanjem nastoji utvrditi koliko su nastavnici u školama otvoreni za prihvatanje i inkorporiranje savremenih nalaza iz oblasti genetike ponašanja u nastavnu praksu. Treba naglasiti i da ovo istraživanje delimično predstavlja replikaciju studije koje su sprovele Krosvajt i Azburi (Crosswaite \& Asbury, 2018), sa tom razlikom što su implicitna predubeđenja u ovom radu ispitana na nešto drugačiji način (pomoću dve zasebne dimenzije - inkrementalnost i entitet), a dodatni cilj je i pokušaj konstrukcije modela kojim bi se stekao detaljniji uvid u relacije između varijabli obuhvaćenih ovim istraživanjem. Naime, kako noviji nalazi (npr. Abd-El-Fattah \& Yates, 2006, İlhan \& Cetin, 2013) ukazuju na to da implicitne teorije inteligencije 
predstavljaju dve zasebne dimenzije, a ne bipolarni konstrukt, u ovom radu mindset je proširen na dve skale - inkrementalno i entitetsko stanovište o prirodi inteligencije. Dodatni cilj bio je usmeren na ispitivanje potencijalnih razlika u svim ispitivanim konstruktima s obzirom na sociodemografske karakteristike nastavnika.

\section{METOD}

\section{Uzorak i postupak}

U istraživanju je učestvovalo 225 učitelja, nastavnika i profesora sa teritorije Republike Srbije, pri čemu uzorak nije bio ujednačen po polu $(88.5 \%$ ženskog pola; $\chi^{2}=133.97, p<.01$ ). Ovakva polna struktura je u skladu sa polnom strukturom nastavnog osoblja u Republici Srbiji, s obzirom na to da se žene više bave ovim poslom ( $73 \%$ žena u osnovnoškolskim, $66 \%$ u srednjoškolskim ustanovama; Republički zavod za statistiku, 2019). Starosni opseg ispitanika kretao se od 24 do 60 godina $(M=42.90, S D=9.03)$ ili izraženo u mesecima radnog staža, od 1 do 480 meseci $(M=185.96 ; S D=114.25)$. U uzorku je najmanje bilo učitelja i učiteljica $(24.3 \%)$, potom nastavnika koji predaju učenicima od petog do osmog razreda $(32.3 \%)$, dok je značajno više bilo srednjoškolskih profesora $\left(43.4 \% ; \chi^{2}=\right.$ $12.38, p<.01)$. Kada se u obzir uzmu samo profesori zaposleni u srednjim školama, $49 \%$ je bilo zaposleno u gimnazijama, a $51 \%$ u stručnim školama. U uzorku je značajno više bilo nastavnika iz gradske $(72.6 \%)$ nego iz seoske sredine $\left(\chi^{2}=43.95\right.$, $p<.01)$.

Istraživanje je sprovedeno $\mathrm{u}$ sklopu studentskih obaveza tokom kursa na osnovnim akademskim studijama. Podaci su prikupljeni tokom novembra 2019. godine putem onlajn platforme, koja je pored baterije upitnika sadržala i informisanu saglasnost. U saglasnosti su bili navedeni i objašnjeni cilj i svrha istraživanja, a ispitanicima je garantovana zaštita ličnih podataka i anonimnost odgovora. Upitnici su distribuirani putem društvene mreže Facebook, u grupama čiji su članovi prosvetni radnici Republike Srbije. Pre pristupanja upitnicima, u samom uputstvu ispitanicima je dato nekoliko osnovnih informacija o bihejvioralnoj genetici kao naučnoj oblasti, kako bi, u slučaju da nisu prethodno bili upoznati sa njom, mogli adekvatno da odgovore na dalja pitanja. Za popunjavanje upitnika bilo je potrebno između 10 i 15 minuta. 


\section{Instrumenti}

Skala implicitnih teorija inteligencije (ITIS: Implicit Theories od Intelligence Scale, Abd El Fatah \& Yates, 2006). Ova skala je namenjena proceni entitetskih (7 stavki; npr. Rođen si sa nepromenljivom količinom inteligencije) i inkrementalnih (7 stavki; npr. Napor koji ulažeš poboljšava tvoju inteligenciju) uverenja u vezi sa prirodom inteligencije. Skalu su na srpski jezik preveli istraživači sa Filozofskog fakulteta u Novom Sadu, a skala je već korišćena u ranijim istraživanjima (npr. Milovanović, 2016). Odgovori na stavke ove skale daju se na četvorostepenoj skali Likertovog tipa (od 1 - uopšte se ne slažem do $4-u$ potpunosti se slažem).

Skala otvorenosti prema genetičkim istraživanjima $u$ obrazovanju (Openness to Genetic Research in Education - OGRE, Crosswaite \& Asbury, 2018). Skala je namenjena proceni zainteresovanosti i spremnosti nastavnika za primenu nalaza bihejvioralno-genetičkih istraživanja u nastavničkoj praksi (Prilog 1). Na srpski jezik je, u saradnji sa autorkama skale, adaptirana od strane autora ovog rada dvostrukim prevodom. Skala se sastoji od pet stavki, a format odgovora je petostepena Likertova skala (od 1 -uopšte se ne slažem do 5 - u potpunosti se slažem). Struktura ove skale je jednofaktorska, što potvrđuju i rezultati paralelne analize. Nakon rekodovanja negativno formulisanih stavki, viši skorovi ostvareni na ovoj skali tretirani su kao veća otvorenost prema genetičkim istraživanjima $u$ obrazovanju.

Test znanja iz oblasti bihejvioralne genetike (Knowledge about behavioural genetics, Crosswaite \& Asbury, 2018). Deset stavki ove skale formulisano je na osnovu „10 repliciranih nalaza iz oblasti bihejvioralne genetike“ (10 replicated findings from behavioural genetics, Plomin et al., 2016), a stavke su prilagođene na način da budu razumljive ispitanicima i praćene su primerom (Prilog 2). Na srpski jezik je, u saradnji sa autorkama, adaptirana od strane autora ovog rada dvostrukim prevodom. Format odgovora na ove stavke je binarni (tačno/netačno). Format ocenjivanja je takođe binarni, pri čemu svaki netačan odgovor nosi 0 , a svaki tačan odgovor 1 bod.

Relativni uticaj gena i sredine na osobine relevantne za obrazovanje $-N-N$ (Prilog). Skala je konstruisana za potrebe ovog istraživanja, a nastala je po ugledu na jednoajtemsku skalu relativnog uticaja gena i sredine na kognitivne sposobnosti (N-N: The relative influence of nature and nurture on cognitive ability, Crosswaite \& Asbury, 2018). Pored kognitivnih sposobnosti, nova skala obuhvata i procenu uticaja gena i sredine na osobine ličnosti koje su obuhvaćene petofaktorskim modelom ličnosti (Costa \& McCrae, 1992), s obzirom na to da osobine ličnosti 
predstavljaju najčešće ispitivane nekognitivne faktore u kontekstu obrazovanja (Furnham, Monsen, \& Ahmetoglu, 2009) čiji su efekti na školsko i akademsko postignuće potvrđeni u ranijim istraživanjima (npr. Hakimi, Hejazi \& Lavasani, 2011; Steinmayr \& Spinath. 2008). Krajnji ishod je skala sa šest stavki na koje su ispitanici davali odgovor putem petostepene skale Likertovog tipa (od $1-u$ potpunosti pod uticajem gena do 5 - U potpunosti pod uticajem sredine). Kako je ova skala prvi put primenjena u ovom istraživanju, proverena je i njena struktura. Rezultati konfirmatorne faktorske analize ukazali su na unidimenzionalnost ove skale $\left(\chi^{2}(d f)\right.$ FAMSO $=16.75(8), p=.03, \chi^{2} / d f=2.09$, CFI $=.97$, TLI $=.95$, RMSEA $=.07$, SRMR $=.04)$.

Pouzdanosti svih skala izražene koeficijentom interne konzistencije, koji se najčešće koristi u psihološkim istraživanjima (Peterson \& Kim, 2013), navedeni su u delu o deskriptivnim statitičkim pokazateljima (Tabela 1).

\section{Statistička obrada podataka}

Sve analize sprovedene su $\mathrm{u}$ statističkom paketu AMOS, SPSS21 (Arbuckle, 2012). Nakon izračunavanja sumativnih i prosečnih skorova u analizi deskriptivnih pokazatelja, svi podaci su standardizovani, s obzirom na to da potiču sa Likertovih skala različitog stepena. Dalje analize (korelaciona analiza i analiza putanje) vršene su na standardizovanim skorovima.

\section{REZULTATI}

Deskriptivni statistički pokazatelji

Deskriptivni statistički pokazatelji korišćenih mera prikazani su u Tabeli 1. Uvidom u vrednosti pokazatelja spljoštenosti i zakošenosti može se zaključiti da se skorovi na svim upitnicima distribuiraju po normalnoj raspodeli, tj. da ne izlaze iz opsega konvencionalno prihvatljivih vrednosti \pm 1.5 (Tabachnick \& Fidell, 2013). Pouzdanosti svih skala se takođe kreću u opsegu prihvatljivih vrednosti, $\alpha>.60$ (Loewenthal, 2004). 
Tabela 1: Deskriptivni statistički pokazatelji ispitivanih varijabli

\begin{tabular}{lcccccccc}
\hline & Min & Max & TAS & $M$ & $S D$ & $S k$ & $K u$ & $\alpha$ \\
\hline znanje & 0 & 9 & 5 & 4.40 & 1.70 & 0.34 & -0.40 & .67 \\
OGRE & 7 & 35 & 21 & 26.39 & 4.83 & -0.12 & -0.37 & .70 \\
inkrementalne t. & 7 & 28 & 17.5 & 14.00 & 3.29 & -0.01 & -0.14 & .79 \\
entitetske t. & 7 & 28 & 17.5 & 20.30 & 3.50 & -0.53 & 1.24 & .69 \\
N-N & 7 & 35 & 21 & 22.12 & 4.83 & -0.54 & 1.26 & .80 \\
\hline
\end{tabular}

Napomena. OGRE - Otvorenost prema genetičkim istraživanjima u obrazovanju; $N-N-$ uverenje o relativnom uticaju gena i sredine; Min - minimalni skor; Max - maksimalni skor; $T A S$ - teorijska aritmetička sredina, $M$ - empirijska aritmetička sredina; $S D$ - standardna devijacija; $S k$ - mera zakošenosti; $K u$ - mera spljoštenosti; $\alpha$ - Kronbahov koeficijent pouzdanosti.

Uvidom u izraženost varijabli može se ustanoviti da su nastavnici skloniji ispoljavanju entitetskih stanovišta u vezi sa prirodom inteligencije, kao i da su otvoreni za nova saznanja iz oblasti bihejvioralne genetike. S druge strane, znanje koje poseduju o relativnom uticaju gena i sredine na oblikovanje osobina relevantnih za obrazovanje, kao i procena tih uticaja se kreću u opsegu teorijski pretpostavljenih srednjih vrednosti, blago iznad ili ispod proseka.

\section{Relacije između ispitanih varijabli i sociodemografske razlike}

Uvidom u interkorelacije ispitivanih mera (Tabela 2) kao niska, ali značajna, izdvaja se pozitivna povezanost između inkrementalnih teorija inteligencije i uverenja o relativnom uticaju gena i sredine $(\mathrm{N}-\mathrm{N})$ i to u smeru u kom nastavnici skloni shvatanju inteligencije kao psihološke karakteristike na koju se može uticati učenjem i usavršavanjem, procenjuju da je sredina ta koja ima veći uticaj na osobine relevantne za obrazovanje. Povezanost između entitetskih teorija i otvorenosti prema bihejvioralno-genetičkim istraživanjima (OGRE) je negativnog smera, odnosno nastavnici koji pokazuju izraženu sklonost ka shvatanju inteligencije kao nepromenljive datosti manje su otvoreni za primenu nalaza bihejvioralne genetike u obrazovnoj praksi. Izdvaja se i negativna povezanost znanja iz oblasti bihejvioralne genetike i N-N uverenja. Preciznije, nastavnici koji imaju manje znanja iz oblasti bihejvioralne genetike procenjuju sredinske faktore kao značajnije u oblikovanju osobina relevantnih za obrazovanje. 
Tabela 2: Interkorelacije skala

\begin{tabular}{lccccc}
\hline & znanje & OGRE & $\begin{array}{c}\text { inkrementalne } \\
\text { teorije }\end{array}$ & $\begin{array}{c}\text { entitetske } \\
\text { teorije }\end{array}$ & N-N \\
\hline znanje & - & & & & \\
OGRE & .09 & - & & & \\
inkrementalne teorije & .01 & -.10 & - & - \\
entitetske teorije & .05 & $-.16^{*}$ & -.03 & -.11 & - \\
$\mathrm{N}-\mathrm{N}$ & $-.23 * *$ & .06 & $.12^{*}$ & & \\
\hline Napomena. $* p<.05 . * * p<.01$. & & &
\end{tabular}

Rezultati sprovedene višesmerne analize varijanse ukazuju na to da ne postoje statistički značajne razlike $\mathrm{u}$ ispitanim varijablama $\mathrm{s}$ obzirom na sociodemografske karakteristike ispitanika (Vrsta škole: Wilks' $\lambda=.97, F=0.66, p$ $=.77, \eta^{2}=.02$; Obrazovni stadijum: Wilks' $\lambda=.94, F=1.39, p=.18, \eta^{2}=.03$; Mesto škole: Wilks' $\lambda=.98, F=0.69, p=.63, \eta^{2}=.02$; Pol: Wilks' $\lambda=.99, F=$ $\left.0.64, p=.67, \eta^{2}=.01\right)$.

\section{Strukturni model - analiza putanje}

Kako bi se ispitale relacije između varijabli obuhvaćenih ovim istraživanjem, primenila se analiza putanje, a kao procenitelj značajnosti modela korišćena je metoda maksimalne verodostojnosti. Status egzogenih varijabli (medijatori) imaju znanje iz oblasti bihejvioralne genetike, otvorenost ka bihejvioralno-genetičkim istraživanjima u obrazovanju (OGRE) i uverenje o relativnom doprinosu gena i sredine (kriterijum), dok status endogenih varijabli (prediktori) imaju implicitne teorije inteligencije (inkrementalne i entitetske). Sve varijable u modelu su manifestne. Testirani model zasnovan je na prethodnim stanovištima (Crosswaite \& Asbury, 2018) da implicitna predubeđenja u vezi sa prirodom inteletkualnih sposobnosti determinišu otvorenost pojedinca za usvajanje novih istraživačkih saznanja u vezi sa intelektualnim funkcionisanjem, što nadalje ostvaruje uticaj na stavove o urođenosti, odnosno stečenosti, kognitivnih aspekata funkcionisanja.

Model adekvatno odgovara podacima (Tabela 3), na šta ukazuju indeksi podesnosti modela: vrednost hi-kvadrat testa koja nije statistički značajna, normirani hi-kvadrat, odnosno količnik hi-kvadrata i broja stepeni slobode $(\chi 2 / d f)$ manji je od 2 (Lazarević, 2008), CFI i TLI su veći od .90, dok je RMSEA manja od .08, (Hu \& Bentler, 1999). 
Tabela 3. Indikatori fita testiranog modela odnosa implicitnih teorija inteligencije, otvorenosti prema genetičkim istraživanjima, znanja i procene relativnog doprinosa gena $\mathrm{i}$ sredine

\begin{tabular}{cccccccc}
\hline & $\chi^{2}(d f)$ & $p$ & $\chi 2 / d f$ & CFI & TLI & RMSEA & BIC \\
\hline model & $2.47(2)$ & .29 & 1.23 & .98 & .91 & .03 & 39.45
\end{tabular}

Napomena. $\chi 2(d f)$ - Hi kvadrat (broj stepeni slobode); $p$ - nivo značajnosti Hi kvadrata; $\chi 2 / d f$ - količnik Hi kvadrata i broja stepeni slobode; CFI - Indeks komparativnog fitovanja (Comparative fit index); TLI - Tucker-Lewis indeks; RMSEA - Kvadratni koren prosečne kvadrirane greške aproksimacije (Root-mean-square error of approximation); BIC bejzijanski informacioni kriterijum (Bayesian information criterion).

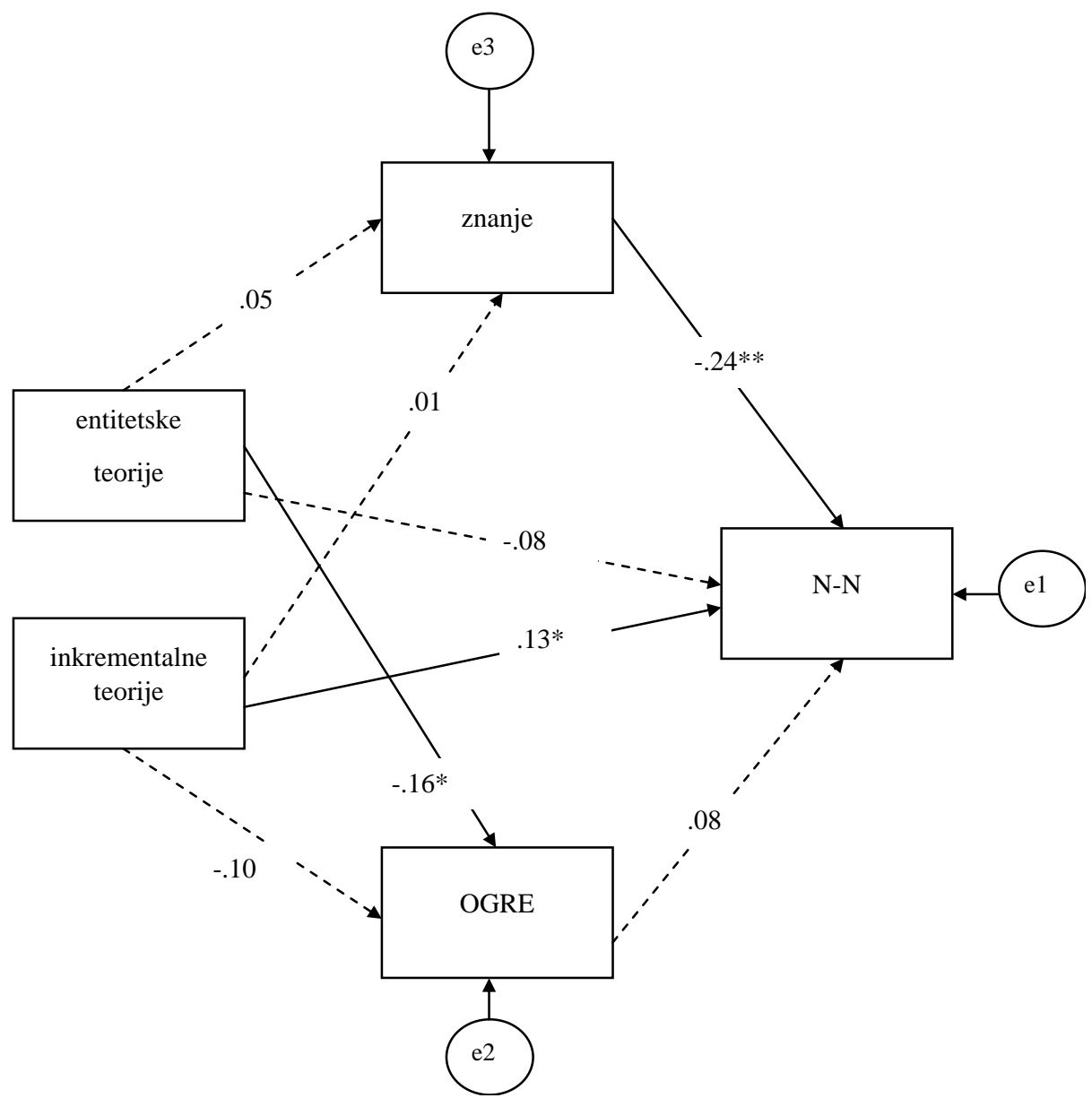

Slika 1. Strukturni model relacija implicitnih teorija inteligencije, OGRE-a, znanja iz bihejvioralne genetike i N-N uverenja 
$\mathrm{Na}$ osnovu rezultata analize putanje može se zaključiti da inkrementalne teorije inteligencije ostvaruju direktan i pozitivan efekat samo na N-N, a entitetske teorije inteligencije ostvaruju značajan negativan efekat na otvorenost prema bihejvioralno-genetičkim istraživanjima. Preciznije rečeno, nastavnici skloni shvatanju inteligencije kao promenljive psihološke karakteristike, skloniji su i proceni uticaja sredine kao značajnijih, dok nastavnici skloni uverenjima o inteligenciji kao datosti pokazuju nižu otvorenost prema bihejvioralno-genetičkim istraživanjima. Ostali efekti implicitnih teorija nisu se izdvojili kao značajni. Rezultati ukazuju i na to da se izdvaja još jedan značajan negativan efekat koji znanje iz oblasti bihejvioralne genetike ostvaruje na N-N, odnosno, nastavnici koji imaju manje znanja iz ove oblasti, procenjuju uticaje genskih faktora kao značajnije u odnosu na sredinske uticaje. Važno je naglasiti da su ostvareni efekti veoma niskog intenziteta, kao i da ne postoji medijatorska uloga otvorenosti prema bihejvioralno-genetičkim istraživanjima i znanja o bihejvioralnoj genetici u relaciji između implicitnih teorija inteligencije i procene uloge gena-sredine (N-N).

\section{DISKUSIJA}

Istraživanje koje je prikazano $u$ ovom radu sprovedeno je u cilju utvrđivanja relacija između implicitnih teorija inteligencije i nastavničkih uverenja o relativnom uticaju gena i sredine na osobine relevantne za obrazovanje. Cilj je bio utvrditi i efekte koje u ovoj relaciji ostvaruju znanje iz oblasti bihejvioralne genetike i otvorenost nastavnika za primenu bihejvioralno-genetičkih nalaza $\mathrm{u}$ pedagoškoj praksi.

Rezultati ukazuju na direktan i pozitivan doprinos sklonosti inkrementalnim uverenjima o prirodi inteligencije u objašnjenju procene udela gena $i$ sredine. Nastavnici koji su skloniji shvatanju inteligencije kao podložne promenama i usavršavanju procenjuju uticaj sredine kao značajniji. Ovakav smer je i očekivan s obzirom na to da se inkrementalna uverenja zasnivaju na shvatanju inteligencije kao psihološke karakteristike na koju se može uticati učenjem i uvežbavanjem. Nalaz o uskoj povezanosti implicitnih uverenja o prirodi inteligencije i sklonosti uverenjima o etiologiji individualnih razlika može se pronaći i u prethodnim istraživanjima (npr. Crosswaite \& Asbury, 2018), mada su implicitne teorije inteligencije bile konceptualizovane na nešto drugačiji način. Čini se da se u laičkim interpretacijama heritabilnost često izjednačava sa determinizmom, što potencijalno može predstavljati objašnjenje za nalaz da oni nastavnici koji su skloni shvatanju inteligencije kao promenljive procenjuju uticaj sredinskih faktora kao značaniji. 
Značajan direktan efekat na procenu udela gena i sredine u oblikovanju kognitivnih sposobnosti i osobina ličnosti ostvaruje i nivo znanja koji nastavnik ima u oblasti bihejvioralne genetike. Ovakav nalaz predstavlja izvesnu novinu s obzirom da se nivo znanja u dosadašnjim radovima (npr. Castera \& Clement, 2014) nije izdvajao kao značajan. Izdvojena relacija je negativnog smera, što implicira da su nastavnici, koji su manje upoznati sa nalazima u ovoj oblasti, skloniji proceni sredine kao značajnije u oblikovanju konstrukta relevantnih za proces obrazovanja. Ovakav nalaz se često izdvaja u slučaju (najčešće ispitivanih) kognitivnih sposobnosti. Preciznije rečeno, česta je laička pogrešna interpretacija etiologije individualnih razlika u kognitivnim sposobnostima koja se ogleda upravo u prenaglašavanju sredinskih uticaja. Ovakva pogrešna uverenja još su izraženija kada su u pitanju procene koje se tiču sposobnosti na ranom dečjem uzrastu, na kom genetski faktori imaju najveći uticaj (Haworth et al., 2010).

Naposletku, kao značajan izdvojio se i negativan doprinos entitetskih uverenja u objašnjenju otvorenosti nastavnika za primenu bihejvioralno-genetičkih nalaza u obrazovanju. Preciznije rečeno, nastavnici koji su skloni shvatanju inteligencije kao nepromenljive datosti pokazuju manje interesovanje za saznanja iz oblasti bihejvioralne genetike i generalno manju spremnost za prihvatanje ovih nalaza u usmeravanju nastavničke prakse. Nastavnici koji zastupaju entitetska stanovišta su u poređenju sa zastupnicima inkrementalnih uverenja skloniji kategorizaciji učenika na tipične, napredne i ,,manje pametne“ (Dweck, 1999), što može dovesti do stvaranja pretpostavki o sposobnosti učenika da uče i napreduju, te generalno profitiraju od truda nastavnika. Nadalje, ukoliko je nastavnik sklon uverenju o prirodi inteligencije kao konstante na koju se ne može uticati učenjem, on svoj doprinos učenikovom usavršavanju shvata ograničenim, a svoju ulogu u tom procesu pasivnijom (Crosswaite \& Asbury, 2019), što verovatno dovodi i do manje motivisanosti u pogledu prihvatanja novih smernica za koncipiranje nastave.

Uloga medijatora otvorenosti prema istraživanjima bihejvioralne genetike u obrazovanju i znanja koje nastavnici imaju u ovoj oblasti nije potvrđena. Kako je ovo prvi pokušaj formulisanja modela koji bi opisao relacije svih ispitanih konstrukata, ovaj nalaz bi zahtevao replikaciju. S druge strane, na osnovu rezultata ovog istraživanja izdvojeni su glavni efekti i stekao se jasniji uvid u relacije između ispitivanih varijabli.

Dodatni cilj ovog rada bio je ispitati razlike u svim ispitanim konstruktima s obzirom na sociodemografske karakteristike nastavnika. Za razliku od većine dosadašnjih nalaza (npr. Georgiou, 2008; Hildebrandt \& Eom, 2011) rezultati ovog istraživanja nisu potvrdili ovu pretpostavku. Moguće objašnjenje ovog nalaza je to 
da se u Srbiji bihejvioralna genetika kao oblast tek razvija, a nastavnici u toku svog formalnog obrazovanja ne stiču znanja iz ove oblasti. Iz tog razloga nastavnici koji su učestvovali u ovom istraživanju, bez obzira na uzrast učenika kojima predaju i druge sociodemografske karakteristike, pokazuju sličan nivo poznavanja nalaza iz oblasti bihejvioralne genetike, koji je blago ispod proseka.

\section{ZAKLJUČAK}

Kako je bihejvioralna genetika relativno mlada naučna oblast koja se sve više razvija, važni nalazi do kojih istraživači u ovom polju dolaze tek treba da dostignu svoju praktičnu primenu i razumevanje od strane opšte populacije u koju se svakako ubrajaju i prosvetni radnici. Nesumnjiv je značaj koji bi praktična primena ovih nalaza imala u obrazovanju, kao najvažnijoj ,,intervenciji“ kojom društvo može oblikovati pojedinca (Krapohl et al., 2014). Zbog toga je neophodno uključiti nastavnike kao učesnike u debati na ovu temu, dok kao preduslov za to stoji i uključivanje (bihejvioralne) genetike u sam proces školovanja nastavnika.

Nalazi ovog istraživanja ukazali su na značaj koji ostvaruju znanje iz oblasti bihejvioralne genetike i implicitne teorije inteligencije u objašnjenju razlika u uverenjima o značaju gena i sredine u oblikovanju kognitivnih sposobnosti i osobina ličnosti. Ovim konstruktima je u dosadašnjim istraživanjima bilo posvećeno manje pažnje, s obzirom na to da su istraživači bili više usmereni na ispitivanje sociodemografiskih karakteristika kao potencijalnog uzroka ovih razlika. Nalazi ovog istraživanja zahtevaju replikaciju, prvenstveno zbog neujednačenosti nastavnika prema sociodemografskim karakteristikama u uzorku. Pored toga treba naglasiti i to da su dobijeni efekti prilično niski. Ovako konstruisana N-N skala prvi put je primenjena u ovom istraživanju, te bi, iako je pokazala zadovoljavajuću pouzdanost, trebalo ispitati njene metrijske karakteristike na reprezentativnijem i brojnijem uzorku. Buduća istraživanja bi trebalo da se sprovode u smeru formulisanja modela kojim bi se bolje opisali odnosi između ispitanih konstrukata, ali i njegovim proširivanjem. Idealno bi bilo kad bi se uvele obuke nastavnika u cilju sticanja znanja iz oblasti bihejvioralne genetike, te upoznavanjem sa fenomenima poput implicitnih uverenja o prirodi intelektualnih sposobnosti i uticaju koji ona mogu imati kako na nastavu tako i na učenike. Organizacija diskusionih grupa nastavnika je takođe način putem kog bi nastavnici mogli steći jasniji uvid i eventualno korigovati svoja implicitna uverenja. Na kraju treba istaći i to da bi uvođenje treninga nastavnika trebalo da bude praćeno i longitudinalnom studijom u kojoj bi se mogla pratiti njegova efikasnost u pogledu promene implicitnih uverenja nastavnika. $\mathrm{S}$ obzirom na to da su $\mathrm{u}$ Srbiji rezultati prve 
blizanačke studije već dostupni, nesumnjivo je da će različite praktične delatnosti, među kojima je i obrazovanje, biti u mogućnosti da koriste i implementiraju neke od tih rezultata u svoj radni proces. Neki od tih modela inkorporiranja znanja iz oblasti genetike ponašanja $u$ vaspitno-obrazovni proces već se koriste $u$ školama drugih država (Asbury \& Plomin, 2013).

S obzirom na veliki društveni i praktični značaj, te na rezultate istraživanja koji ukazuju na pozitivne aspekte nastave organizovane u kontekstu genetički senzitivne učionice (Haworth \& Plomin, 2012), ovoj temi nesumnjivo treba pridati veću važnost i pažnju u budućim istraživanjima nastavničke prakse u Srbiji.

Luna N. Radević, Ilija Z. Milovanović

\section{RELATIONS BETWEEN IMPLICIT THEORIES OF INTELLIGENCE AND BELIEFS ABOUT THE ETIOLOGY OF INDIVIDUAL DIFFERENCES RELEVANT TO EDUCATION: THE ROLE OF BEHAVIORAL GENETICS IN TEACHING PRACTICE}

\section{Summary}

Although there is a piece of evidence about extensive research examining the influence of genetic and environmental factors on educational traits, only few studies so far have explored teachers' beliefs about the development of individual differences related to education in light of hereditary and environmental factors. This study aimed to examine the relationships between implicit theories of intelligence and the beliefs that teachers have about the relative influence of genes and the environment in explaining individual differences which are relevant to education. In this studycognitive abilities and personality traits were considered together, given that in previous research intelligence and personality traits were most systematically considered in the fields of behavioral genetic and educational psychology. The aim was to examine the effects that knowledge of behavioral genetics and openness to behavioral genetic research in education have in the aforementioned relationship. Also, we examined the role of sociodemographic characteristics in explaining the differences between teachers in all examined variables.In the research participated 225 teachers, male and female professors (88.5\% female) in the territory of the Republic of Serbia (average age 42.9 years) . The results indicate significant and direct contributions made by incremental theories of intelligence in the positive direction, and knowledge in the field of behavioral genetics in the negative, beliefs about the importance of genes and the environment in cognitive abilities and personality traits. Entity theories make a significant negative contribution to teachers' openness to behavioral-genetic research. No differences concerning the sociodemographic characteristics of teachers were detected. The findings of this study indicated the importance of knowledge in the field of behavioral genetics and implicit theories of intelligence in explaining differences in teachers' beliefs about the importance of genes and the environment in shaping individual 
differences related to education. Given the great social and practical significance of research results that indicate the positive aspects of teaching organized in the context of genetically sensitive classroom, undoubtedly this topic should be given more importance and attention in future research.

Key words: behavioral genetics, implicit theories of intelligence, N-N controversy, teachers

\section{LITERATURA}

Abd-El-Fattah, S. M., \& Yates, G. C. R. (2006). Implicit theory of intelligence scale: Testing for factorial invariance and mean structure. In: Australian Association for Research in Education Conference, Adelaide, South Australia (pp. 1-14).

Arbuckle, J. L. (2012). IBM SPSS AMOS (version 21.0)[computer program]. Chicago, IL: IBM.

Asbury, K., \& Plomin, R. (2013). G is for genes: The impact of genetics on education and achievement (Vol. 24). John Wiley \& Sons (pp. 100-112).

Benbow, C. P. (1992). Academic achievement in mathematics and science of students between ages 13 and 23: Are there differences among students in the top one percent of mathematical ability? Journal of Educational Psychology, 84(1), 51. https://doi.org/10.1037/0022-0663.84.1.51

Blackwell, L. S., Trzesniewski, K. H., \& Dweck, C. S. (2007). Implicit theories of intelligence predict achievement across an adolescent transition: A longitudinal study and an intervention. Child Development, 78, 246-263. doi:10.1111/j.1467-8624.2007.00995.x

Carr, P. B., \& Dweck, C. S. (2011). Intelligence and motivation. In R. J. Sternberg \& S. B. Kaufman (Eds.), The Cambridge handbook of intelligence (pp. 748-70). New York: Australian Journal of Teacher Education.

Castera, J., \& Clement, P. (2014). Teachers' conceptions about the genetic determinism of human behaviour: A survey in 23 countries. Science and Education, 23(2) 417-443. https://doi.org/10. 1007/s11191-012-9494-0

Costa, P. T., \& McCrae, R. R. (1992). Neo Pi-R. Odessa, FL: Psychological Assessment Resources.

Crosswaite, M. L. (2018). Teacher beliefs about the aetiology of individual differences in educationally relevant traits, and the relevance of behavioural genetics to education (Doctoral dissertation, University of York).

Crosswaite, M., \& Asbury, K. (2019). Teacher beliefs about the aetiology of individual differences in cognitive ability, and the relevance of behavioural 
genetics to education. British Journal of Educational Psychology, 89(1), 95-110. doi:10.1111/bjep.12224

Devonshire, I., \& Dommett, E. (2010). Neuroscience: Viable Applications in Education? The Neuroscientist, 16(4), 349-356. https://doi.org/10.1177/ 1073858410370900

Dweck, C. S. (1986). Motivational processes affecting learning. American psychologist, 41(10). https://doi.org/10.1037/0003-066X.41.10.1040

Dweck,C.(1999). Self-theories: Their role in motivation, Personality, and Development (Essays in Social Psychology) (1st ed.). Hove, UK: Psychology Press.

Furnham, A., Monsen, J., \& Ahmetoglu, G. (2009). Typical intellectual engagement, Big Five personality traits, approaches to learning and cognitive ability predictors of academic performance. British Journal of Educational Psychology, 79(4),

769-782. https://doi.org/10.1348/978185409X412147

Georgiou, S. (2008). Beliefs of experienced and novice teachers about achievement. Educational Psychology, 28(2), 119-131.

Gietz, C., \& McIntosh, K. (2014). Relations between student perceptions of their school environment and academic achievement. Canadian Journal of School Psychology, 29(3), 161-176. doi: https://doi.org/10.1177/ 0829573514540415

Hakimi, S., Hejazi, E., \& Lavasani, M. G. (2011). The relationships between personality traits and students' academic achievement. Procedia-Social and Behavioral Sciences, 29, 836-845. https://doi.org/10.1016/j.sbspro.2011.11.312

Haworth, C., \& Plomin, R. (2012). Genetics and education: Toward a genetically sensitive classroom. In K. R. Harris, S. Graham, T. Urdan, C. B. McCormick, G. M. Sinatra, \& J. Sweller (Eds.), APA educational psychology handbook, Vol 1: Theories, constructs, and critical issues (pp. 529-559). American Psychological Association.

Haworth, C., Wright, M., Luciano, M., Martin, N., de Geus, E., van Beijsterveldt, C., ...Plomin, R. (2010). The heritability of general cognitive ability increases linearly from childhood to young adulthood. Molecular Psychiatry, 15(11), 1112-1120. https://doi.org/10.1038/mp.2009.55

Hildebrandt, S., \& Eom, M. (2011). Teacher professionalization: Motivational factors and the influence of age. Teaching and Teacher Education, 27(2), 416-423. https://doi.org/10.1016/j.ta te.2010.09.011 
Hong, Y-Y., Chiu, C-y, Dweck, C. S., Lin, D. M. S., \& Wan, W. (1999). Implicit theories, attributions, and coping: A meaning system approach. Journal of Personality and Social Psychology, 77, 588-599. doi:10.1037//00223514.77.3.588 https://doi.org/10.1080/01443410701468716

Hu, L. T., \& Bentler, P. M. (1999). Cutoff criteria for fit indexes in covariance structure analysis: Conventional criteria versus new alternatives. Structural Equation Modeling: A Multidisciplinary Journal, 6(1), 1-55. doi:10.1080/10705519909540118

İlhan, M., \& Çetin, B. (2013). The Turkish Adaptation of Implicit Theory of Intelligence Scale: The Validity and Reliability Study. Journal of Science and Mathematics Education, 7(1), 191-221. doi:10.12973/nefmed159

Krapohl, E., Rimfeld, K., Shakeshaft, N. G., Trzaskowski, M., McMillan, A., Pingault, J. B., ... \& Plomin, R. (2014). The high heritability of educational achievement reflects many genetically influenced traits, not just intelligence. Proceedings of the national academy of sciences, 111(42), 15273-15278.

Lazarević, Lj. (2008). Primena indeksa podesnosti u testiranju teorijskih modela u psihologiji: Mogućnosti i ograničenja. Zbornik Instituta za pedagoška istraživanja, 40(1), 101-121. doi:10.2298/ZIPI0801101

Leroy, N., Bressoux, P., Sarrazin, P., \& Trouilloud, D. (2007). Impact of teachers' implicit

theories and perceived pressures on the establishment of an autonomy supportive classroom. European Journal of Psychology of Education, 22(4), 529-545. doi: 10.1007/bf03173470

Loewenthal, K. M. (2004). An introduction to Psychological Tests and Scale, $2^{\text {nd }}$ ed. Hove: Pschology Press.

Lynott, D., \& Woolfolk, A. E. (1994). Teachers' implicit theories of intelligence and their educational goals. Journal of Research and Development in Education, 27(4), 253-264.

Milovanović, I. (2016). Implicitne teorije inteligencije i motivacija za učenje matematike kod učenika srednjih škola. Nastava i vaspitanje, 65(3), 509524. 10.5937/nasvas1603509M

Nikolašević, Ž., Bugarski-Ignjatović, V., Milovanović, I., i Raković, S. (2014). Inteligencija i školsko postignuće u svetlu naslednih i sredinskih činilaca. Primenjena psihologija, 7(3), 381-400. https://doi.org/10.19090/pp.2014. $3.381-400$ 
Nikolašević, Ž., Smederevac, S., Ignjatović, V. B., Kodžopeljić, J., Milovanović, I., Prinz, M., \& Budimlija, Z. (2020). Executive functions and intelligence-are there genetic difference? Intelligence, 82, 101480. https://doi.org/10.1016/j.intell.2020.101480

Peterson, R. A., \& Kim, Y. (2013). On the relationship between coefficient alpha and composite reliability. Journal of Applied Psychology, 98(1), 194. doi: 10.1037/a0030767

Plomin, R., \& von Stumm, S. (2018). The new genetics of intelligence. Nature Reviews Genetics, 19(3), 148. doi: 10.1038/nrg.2017.104

Plomin, R., DeFries, J., Knopik, V., \& Neiderhiser, J. (2016). Top 10 replicated findings from behavioral genetics. Perspectives on Psychological Science, 11(1), 3-23. https://doi.org/10. 1177/1745691615617439

Pretzlik, U., Olsson, J., Nabuco, M., \& Cruz, I. (2003). Teachers' implicit views of intelligence predict self-perceptions as learners. Cognitive Development, $18,579-600$

Republički zavod za statistiku (2019). Nastavnici na početku školske godine po polu i dužini radnog vremena. Preuzeto sa: https://data.stat.gov.rs/Home/Result/ 11020201 ?languageCode $=$ sr-Cyrl na dan 21.4.2020.

Ridley, M. (2003). Nature via nurture: Genes. Experience, and what makes us human. New York. (pp. 30-37)

Rimfeld, K., Ayorech, Z., Dale, P., Kovas, Y., \& Plomin, R. (2016). Genetics affects choice of academic subjects as well as achievement. Scientific Reports, 6(1). doi: 10.1038/srep26373

Shively, L. R., \& Ryan, S. C. (2013). Longitudinal changes in college students' implicit theories of intelligence. Social Psychology Education, 16, 241256. doi:10.1007/s11218-012-9208-0

Smederevac, S., Mitrović, D., Sadiković, S., Milovanović, I., Branovački, B., Dinić, B. M., ... \& Stankov, T. V. (2019). Serbian twin registry. Twin Research and Human Genetics, 22(6), 660-666. doi: 10.1017/thg.2019.114

Steinmayr, R., \& Spinath, B. (2008). Sex differences in school achievement: What are the roles of personality and achievement motivation?. European Journal of Personality: Published for the European Association of Personality Psychology, 22(3), 185-209. https://doi.org/10.1002/per.676

Sternberg, R. J. (1990). Metaphors of mind: Conceptions of the nature of intelligence. Cambridge University Press. pp. 200-220.

Stipek, D. J. (2002). Motivation to learn: Integrating theory and practice $\left(4^{\text {th }} \mathrm{ed}\right.$.). Boston, MA: Allyn \& Bacon. 
Stump, S. G., Husman, J., \& Corby, M. (2014). Engineering students' intelligence beliefs and learning. Journal of Engeneering Education, 103(3), 369-387. doi:10.1002/jee.20051

Tabachnick, B. G., \& Fidell, L.S. (2013). Using multivariate statistics, $6^{\text {th }}$ ed. Boston: Pearson.

Turkheimer, E. (2000). Three Laws of Behavior Genetics and What They Mean. Current Directions In Psychological Science, 9(5), 160-164. http://dx.doi.org/10.1111/1467-8721.00084

Walker, S. O., \& Plomin, R. (2005). The nature-nurture question: Teachers' perceptions of how genes and the environment influence educationally relevant behaviour. Educational Psychology, 25(5), 509-516. https://doi.org/10.1080/01443410500046697 


\section{PRILOZI}

\section{Prilog 1}

\section{OGRE}

UPUTSTVO: Ovaj upitnik sadrži tvrdnje koje se odnose na stavove koji se tiču uloge bihejvioralne genetike u obrazovanju i nastavničkoj praksi. Molimo Vas da označite broj koji najviše odgovara Vašem stepenu slaganja sa iznetom tvrdnjom.

\section{1 - UOPŠTE SE NE SLAŽEM ; 2 - DELIMIČNO SE NE SLAŽEM; 3 - NISAM SIGURAN/NA; 4 - DELIMIČNO SE SLAŽEM; 5 - U POTPUNOSTI SE SLAŽEM}

\begin{tabular}{|l|l|l|l|l|l|l|}
\hline & Stavka & \multicolumn{3}{|c|}{ Odgovori } \\
\hline $\mathbf{1}$ & $\begin{array}{l}\text { Istraživanja koja objašnjavaju uticaje genskih i sredinskih } \\
\text { činilaca na kognitivne sposobnosti bi mogla biti korisna za } \\
\text { nastavnike. }\end{array}$ & 1 & 2 & 3 & 5 \\
\hline $\mathbf{2}$ & $\begin{array}{l}\text { Generalno, smatram da bihejvioralna genetika ima važnu } \\
\text { ulogu u obrazovanju. }\end{array}$ & 2 & 3 & 4 & 5 \\
\hline $\mathbf{3}$ & $\begin{array}{l}\text { Ne smatram da nalazi iz oblasti bihejvioralne genetike treba } \\
\text { da se koriste kao smernice za nastavničku praksu u } \\
\text { budućnosti. }\end{array}$ & 2 & 3 & 4 & 5 \\
\hline $\mathbf{4}$ & $\begin{array}{l}\text { Ne bih voleo/la da nalazi istraživanja iz bihejvioralne } \\
\text { genetike utiču na moje nastavničke odluke i praksu. }\end{array}$ & 1 & 2 & 3 & 4 & 5 \\
\hline $\mathbf{5}$ & $\begin{array}{l}\text { Želeo/la bih da znam više o bihejvioralnoj genetici i } \\
\text { implikacijama koje ima na dečji razvoj. }\end{array}$ & 1 & 3 & 4 & 5 \\
\hline
\end{tabular}

\section{Prilog 2}

TZ

UPUTSTVO: Ovaj upitnik sadrži tvrdnje koje se odnose na glavne teme koje bihejvioralna genetika izučava. Molimo Vas da označite da li smatrate da je navedena tvrdnja tačna (T) ili netačna $(\mathbf{N})$.

\begin{tabular}{|l|l|c|c|}
\hline & Stavka & Odgovori \\
\hline $\mathbf{1}$ & Sve psihološke karakteristike su pod značajnim uticajem genetike. & $\mathrm{T}$ & $\mathrm{N}$ \\
\hline $\mathbf{2}$ & Nijedna psihološka karakteristika nije 100\% nasledna. & $\mathrm{T}$ & $\mathrm{N}$ \\
\hline $\mathbf{3}$ & $\begin{array}{l}\text { Naslednost osobina i oblika ponašanja je uzrokovana velikim brojem } \\
\text { različitih gena, pri čemu svaki gen ima mali efekat. }\end{array}$ & $\mathrm{T}$ & $\mathrm{N}$ \\
\hline $\mathbf{4}$ & $\begin{array}{l}\text { Postoji genetska povezanost između nekih osobina i ponašanja, na primer, } \\
\text { inteligencija i uspeh u školi su povezani, jer na njih utiču isti geni. }\end{array}$ & $\mathrm{T}$ & $\mathrm{N}$ \\
\hline $\mathbf{5}$ & $\begin{array}{l}\text { Verovatno postoji jedan gen koji je odgovoran za postojanje razlika u } \\
\text { inteligenciji između ljudi. Pitanje je samo vremena kada će on biti } \\
\text { otkriven. }\end{array}$ & $\mathrm{T}$ & $\mathrm{N}$ \\
\hline $\mathbf{6}$ & $\begin{array}{l}\text { Kako starimo, na našu inteligenciju sve više utiču geni, a sve manje } \\
\text { sredina. }\end{array}$ & $\mathrm{T}$ & $\mathrm{N}$ \\
\hline $\mathbf{7}$ & Roditeljstvo i sredina u kojoj živimo jesu pod uticajem naših gena. & $\mathrm{T}$ & $\mathrm{N}$ \\
\hline
\end{tabular}




\begin{tabular}{|l|l|c|c|}
\hline $\mathbf{8}$ & $\begin{array}{l}\text { Problemi u ponašanju se uglavnom mogu objasniti roditeljskim stilom } \\
\text { vaspitanja. }\end{array}$ & $\mathrm{T}$ & $\mathrm{N}$ \\
\hline $\mathbf{9}$ & $\begin{array}{l}\text { Većina psiholoških poremećaja (npr. ADHD, anksioznost) su samo } \\
\text { ekstremni oblici normalnog ponašanja, a ne genetski uzrokovani } \\
\text { poremećaji. }\end{array}$ & $\mathrm{T}$ & $\mathrm{N}$ \\
$\mathbf{1 0}$ & $\begin{array}{l}\text { Većina blažih i umerenih poremećaja učenja (npr. disleksija) su samo } \\
\text { ekstremi normalnog ponašanja, a ne genetski uzrokovani poremećaji. }\end{array}$ & $\mathrm{T}$ & $\mathrm{N}$ \\
\hline
\end{tabular}

Prilog 3

N-N

UPUTSTVO: Ovaj upitnik se odnosi na Vašu procenu stepena u kom su osobine i sposobnosti koje su relevantne za obrazovanje, pod uticajem gena ili sredine. Molimo Vas da označite broj koji u najvećem stepenu odražava Vaš stav u vezi sa sledećim tvrdnjama:

\section{1 - U POTPUNOSTI POD UTICAJEM GENA; 2 - VIŠE POD UTICAJEM GENA, NEGO POD UTICAJEM SREDINE; 3 - PODJEDNAKO POD UTICAJEM GENA I SREDINE; 4 - VIŠE POD UTICAJEM SREDINE NEGO POD UTICAJEM GENA; 5 - U POTPUNOSTI POD UTICAJEM SREDINE}

\begin{tabular}{|l|l|l|l|l|l|l|}
\hline & Stavka & \multicolumn{3}{|c|}{ Odgovori } \\
\hline $\mathbf{1}$ & U kojoj meri mislite da na inteligenciju utiču geni, odnosno sredina? & 1 & 2 & 3 & 4 & 5 \\
\hline $\mathbf{2}$ & $\begin{array}{l}\text { U kojoj meri mislite da je savesnost pod uticajem gena, odnosno } \\
\text { sredine? (Odnosi se na samodisciplinovano, organizovano i istrajno } \\
\text { stremljenje ka postavljenim ciljevima, uprkos ometanjima.) }\end{array}$ & 1 & 2 & 3 & 4 & 5 \\
\hline $\mathbf{3}$ & $\begin{array}{l}\text { U kojoj meri mislite da je otvorenost ka iskustvu pod uticajem gena, } \\
\text { odnosno sredine? (Odnosi se na spremnost za prihvatanje novih } \\
\text { ideja i nekonvencionalnih vrednosti, sklonost ka istraživanju novog i } \\
\text { nepoznatog, intelektualnu radoznalost i kreativnost.) }\end{array}$ & 1 & 2 & 3 & 4 & 5 \\
\hline $\mathbf{4}$ & $\begin{array}{l}\text { U kojoj meri mislite da je prijatnost pod uticajem gena, odnosno } \\
\text { sredine? (Odnosi se na kvalitet međuljudske orijentacije i izraženost } \\
\text { potrebe za harmoničnim odnosima sa drugima.) }\end{array}$ & 1 & 2 & 3 & 4 & 5 \\
\hline $\mathbf{5}$ & $\begin{array}{l}\text { U kojoj meri mislite da je neuroticizam pod uticajem gena, odnosno } \\
\text { sredine? (Odnosi se na sklonost ka doživljavanju negativnih } \\
\text { emocija, zabrinutosti, osetljivost na stres, te neadekvatne strategije } \\
\text { suočavanja sa stresnim situacijama.) }\end{array}$ & 1 & 2 & 3 & 4 & 5 \\
\hline $\mathbf{6}$ & $\begin{array}{l}\text { U kojoj meri mislite da je ekstraverzija pod uticajem gena, odnosno } \\
\text { sredine? (Odnosi se na kvantitet i intenzitet interakcija sa drugim } \\
\text { ljudima, aktivitet i potrebu za stimulacijom, kao i sklonost ka } \\
\text { doživljavanju pozitivnih emocija.) }\end{array}$ & 1 & 2 & 3 & 4 & 5 \\
\hline
\end{tabular}

